\title{
BACE1 gene variants do not influence BACE1 activity, levels of APP or A $\beta$ isoforms in CSF in Alzheimer's disease
}

\author{
Annica Sjölander ${ }^{* *}$, Henrik Zetterberg ${ }^{1}$, Ulf Andreasson ${ }^{1}$, Lennart Minthon²,3 Kaj Blennow ${ }^{1}$
}

\begin{abstract}
The BACE1 gene encodes the beta-site APP-cleaving enzyme 1 and has been associated with Alzheimer's disease (AD). BACE1 is the most important $\beta$-secretase responsible for the generation of Alzheimer-associated amyloid $\beta$ proteins $(A \beta)$ and may play a role in the amyloidogenic process in AD. We hypothesized that BACE1 gene variants might influence BACE1 activity or other markers for APP metabolism in the cerebrospinal fluid (CSF) and thereby contribute to the development of AD. We genotyped a Swedish sample of 269 AD patients for the rs638405 single nucleotide polymorphism (SNP) in the BACE1 gene and correlated genotype data to a broad range of amyloidrelated biomarkers in CSF, including BACE1 activity, levels of $A \beta_{40}, A \beta_{42}, \alpha$ - and $\beta$-cleaved soluble APP ( $\alpha$-SAPP and $\beta$-SAPP), as well as markers for Alzheimer-type axonal degeneration, i.e., total-tau and phospho-tau ${ }_{181}$. Gene variants of BACE1 were neither associated with amyloid-related biomarkers, nor with markers for axonal degeneration in AD.
\end{abstract}

\section{Findings}

Cleavage of the amyloid precursor protein (APP) by $\beta$ and $\gamma$-secretase gives rise to the amyloid $\beta$-protein $(A \beta)$ found in senile plaques (SP) in Alzheimer's disease (AD). The BACE1 gene encodes the beta-site APP-cleaving enzyme 1 (OMIM 604252), which is involved in $\beta$ secretase activity [1-4]. The BACE1 gene is associated with $\mathrm{AD}[5,6]$ and the BACE1 activity is elevated both in brain tissue and in CSF in AD $[7,8]$. We hypothesized that $B A C E 1$ gene variants might influence the BACE1 activity or other amyloid-related biomarkers related to amyloid in the cerebrospinal fluid (CSF) and thereby contribute to developing $\mathrm{AD}$. We tested a single nucleotide polymorphism (SNP) in the BACE1 gene to evaluate the genetic influence on BACE1 activity, levels of $A \beta_{40}$, $A \beta_{42}, \alpha$ - and $\beta$-cleaved soluble APP ( $\alpha$-sAPP and $\beta$ sAPP) in CSF from AD patients. Further we assessed the BACE1 genetic influence on markers for Alzheimertype axonal degeneration (total-tau and phospho-tau ${ }_{181}$ ). The rs638405 SNP have a high allele frequency with a global frequency of the least common variant of 0.32 .

\footnotetext{
* Correspondence: annica.sjolander@neuro.gu.se

${ }^{1}$ Institute of Neuroscience and Physiology, Department of Neurochemistry and Psychiatry, Sahlgrenska University Hospital, University of Gothenburg, Sweden

Full list of author information is available at the end of the article
}

To our knowledge this is the first study investigates $B A C E 1$ genotype data in relation to BACE1 activity and other amyloid-related biomarkers in CSF from AD patients.

We studied a Swedish Caucasian sample of 269 AD patients (90 men and 179 women, mean age $74.7 \pm 6.3$ years) where CSF levels of total-tau, phospho- $\operatorname{tau}_{181}$ and $\mathrm{A} \beta_{42}$ were known. We measured the BACE1 activity, levels of $\alpha$-sAPP, $\beta$-sAPP and A $\beta_{40}$ in CSF samples from 84 of the patients. All participants were recruited at the Memory Clinic at the Malmö University Hospital. The patients gave informed consent to participate in the study, which was conducted according to the provisions of the Helsinki Declaration and approved by the local ethic committee. The diagnosis of "probable AD" was made according to the NINCDS-ADRDA criteria [9]. No AD patient had any of the known familial forms of autosomal dominant AD.

CSF samples were taken by lumbar puncture. BACE1 activity was determined with a sensitive and specific solution-based assay previously described [10]. Levels of total-tau, phospho-tau ${ }_{181}$ and $A \beta_{42}$ were measured using established ELISA methods $[11,12]$ while $\alpha$-sAPP, $\beta$-sAPP and $A \beta_{40}$ were quantified using MSD immunoassays (Cat\#: K11120E and K111FTE), (Meso Scale Discovery, Gaithersburg, MD, USA). 
Genomic DNA was extracted from whole blood using standard methods. BACE1 alleles were determined using the Dynamic Allele Specific Hybridization (DASH) technique as described earlier [13]. Optimal assay conditions: $1.5 \mathrm{mM} \mathrm{MgCl} 2,200 \mu \mathrm{M}$ dNTPs, $0.05 \mathrm{U} / \mu \mathrm{T} \mathrm{Taq}$ polymerase, $0.15 \mathrm{pmol} / \mu \mathrm{l}$ forward biotinylated primer (5'-Biotin-ATCCGGCGGGAGTGGTATTATG-3'), 0.75 $\mathrm{pmol} / \mu \mathrm{l}$ reverse primer (5'-GTCCATTGATCTCCACCCGCAC-3') (Invitrogen, Life Technologies) and 5$20 \mathrm{ng}$ DNA, 1xPCR buffer in a final volume of $25 \mu \mathrm{l}$. The cycling profile was: 5 min $95^{\circ} \mathrm{C}, 40$ cycles: $30 \mathrm{sec}$ $95^{\circ} \mathrm{C}, 45 \sec 60^{\circ} \mathrm{C}, 1 \mathrm{~min} 72^{\circ} \mathrm{C}$ and a final step of 10 min $72^{\circ} \mathrm{C}$. To identify $B A C E 1$ alleles the probes $5^{\prime}-$ CACAATGATCACCTCATAA-3' and 5'-CACAATGATGACCTCATAA-3' were used.

$A P O E$ genotyping was performed using minisequencing as described before [14]. Gene designations follow the recommendations of HUGO Gene Nomenclature Committee [15].

The genotype and allele frequencies of the BACE1 rs638405 and $A P O E \varepsilon 4$ are shown in table 1 . The analysis of variance (ANOVA) was used to analyze the effects of $B A C E 1$ genetic variants on MMSE, BACE1 activity and CSF protein levels. To test the effects of known risk factors, e.g., age, sex and $A P O E \& 4$ we identified significantly relevant covariates for each outcome variable (MMSE and levels of AD CSF biomarkers) using forward stepwise linear regression. Hardy-Weinberg equilibrium was assessed by $\chi^{2}$ statistics. The criterion for significance was set at $\mathrm{p}<0.05$ for all statistical tests. Statistical analyses were performed with the SYSTAT11 (SYSTAT Software GmbH, Erkrath, Germany) software.

We studied BACE1 gene variants in relation to BACE1 activity and levels of amyloid-related biomarkers in CSF from $\mathrm{AD}$ patients. In the linear regression analysis we found $A P O E \& 4$ to significantly interact with phosphotau18, $\mathrm{A} \beta_{42}$ and MMSE. Subsequently, APOE $\varepsilon 4$ was

Table 1 BACE1 and APOE genotype and allele frequencies in $A D$ patients

\begin{tabular}{lccc}
\hline BACE1 & & & \\
\hline Genotype frequencies & CC & CG & GG \\
$A D(269)$ & $50(0.19)$ & $117(0.43)$ & $102(0.38)$ \\
\hline Allele frequencies & $\mathbf{C}$ & $\mathbf{G}$ & \\
AD (538) & $217(0.40)$ & $321(0.60)$ & \\
\hline$A P O E$ & & & \\
\hline Genotype frequencies & No $\mathbf{\varepsilon 4}$ & One $\mathbf{\varepsilon 4}$ & Two $\mathbf{8 4}$ \\
AD (269) & $74(0.28)$ & $135(0.50)$ & $60(0.22)$ \\
\hline Allele frequencies & $\mathbf{\varepsilon 2 / \varepsilon 3}$ & $\mathbf{8 4}$ & \\
AD (538) & $283(0.53)$ & $255(0.47)$ & \\
\hline
\end{tabular}

Abbreviations: Alzheimer's disease (AD). Number of total genotypes and alleles are given $(\mathrm{N})$. Percentage of total is shown for the genotypes and alleles respectively.
Table 2 BACE1 activity and biochemical markers in CSF and $B A C E 1$ genotypes in $A D$ patients

\begin{tabular}{lcccc}
\hline \multicolumn{5}{c}{ BACE1 genetic variants } \\
CSF protein & CC & CG & GG & $\begin{array}{c}\text { p- } \\
\text { value }\end{array}$ \\
\hline Total-tau $(\mathrm{pg} / \mathrm{ml})$ & $628.8 \pm 38.7$ & $612.7 \pm 29.3$ & $610.0 \pm 33.4$ & 0.699 \\
$\begin{array}{l}\text { Phospho-tau } \\
(\mathrm{pg} / \mathrm{ml})\end{array}$ & $79.7 \pm 3.9$ & $73.8 \pm 2.8$ & $77.7 \pm 3.4$ & 0.506 \\
$\mathrm{~A} \beta_{42}(\mathrm{pg} / \mathrm{ml})$ & $408.7 \pm 11.8$ & $419.4 \pm 9.2$ & $408.3 \pm 9.9$ & 0.575 \\
A $\beta_{40}(\mathrm{pg} / \mathrm{ml})$ & $4869.9 \pm$ & $4894.8 \pm$ & $5030.7 \pm$ & 0.854 \\
& 196.4 & 238.6 & 219.6 & \\
BACE1 $(\mathrm{pM})$ & $29.2 \pm 2.5$ & $31.8 \pm 2.0$ & $33.6 \pm 3.3$ & 0.765 \\
$\alpha$-sAPP $(\mathrm{ng} / \mathrm{ml})$ & $645.8 \pm 77.0$ & $660.5 \pm 40.6$ & $620.5 \pm 41.8$ & 0.962 \\
$\beta$ - -sAPP $(\mathrm{ng} / \mathrm{ml})$ & $393.3 \pm 37.8$ & $408.0 \pm 24.9$ & $399.6 \pm 22.6$ & 0.965 \\
\hline
\end{tabular}

Abbreviations: Alzheimer's disease (AD). Mean values ( \pm SEM) are shown.

Adjusted $p$-values are shown for respective comparison.

included as covariate in the statistic model. We found no effect of $B A C E 1$ gene variants on BACE1 activity or levels of $A \beta_{40}, A \beta_{42}, \alpha$-sAPP and $\beta$-sAPP (Table 2). We compared CSF levels of markers for axonal degeneration (total-tau and phospho-tau ${ }_{181}$ ) between BACE1 gene variants and found no significant differences in protein levels (Table 2). The BACE1 SNP showed no association with MMSE (data not shown).

The APOE allele distribution followed the expected frequencies seen in AD populations (Table 1). Genotype frequencies conformed to Hardy-Weinberg equilibrium in $\mathrm{AD}$ patients.

We hypothesized that $B A C E 1$ gene variants might influence BACE1 activity or levels of amyloid-related biomarkers in the cerebrospinal fluid (CSF) and thereby contribute to the development of AD. A genome-wide screen of $\mathrm{AD}$ families has shown linkage to marker close to BACE1 [16] and the rs638405 SNP has been tested in a number of studies $[5,17]$. Other studies have found association between the BACE1 gene and $\mathrm{AD}[5,18]$. Even though this SNP does not change the protein sequence it still can have functional effects based on earlier findings where $B A C E 1$ influenced levels of $A \beta$ in CSF [6]. We tested if the rs2069456 SNP was associated with BACE1 activity or with levels of $A \beta_{40}, A \beta_{42}, \alpha$-sAPP and $\beta$-sAPP in CSF from AD patients. Further we assessed the influence on total-tau and phospho-tau ${ }_{181}$. Gene variants of $B A C E 1$ were neither associated with amyloid-related biomarkers nor with markers for axonal degeneration. Our results do not support that variants of the $B A C E 1$ gene affects $B A C E 1$ activity or CSF levels of APP or $A \beta$ isoforms in AD.

Acknowledgements

This work was supported by grants from Demensfonden.

Author details

${ }^{1}$ Institute of Neuroscience and Physiology, Department of Neurochemistry and Psychiatry, Sahlgrenska University Hospital, University of Gothenburg, 
Sweden. ${ }^{2}$ Clinical Memory Research Unit, Department of Clinical Sciences Malmö, Lund University, Sweden. ${ }^{3}$ Neuropsychiatric Clinic, Malmö University Hospital, Sweden.

\section{Authors' contributions}

AS participated in the design of the study, performed the genetic analyses, analyzed the data statistically and drafted the manuscript. $\mathrm{HZ}$ participated in the design of the study, helped in analyzing the data and helped in drafting the manuscript. UA performed the activity analyses and the immunoassays and revised the manuscript critically. LM collected the clinical material and revised the manuscript critically. KB participated in the design of the study, helped in analyzing the data and revised the manuscript critically. All authors read and approved the final manuscript.

\section{Competing interests}

The authors declare that they have no competing interests.

Received: 16 June 2010 Accepted: 17 September 2010 Published: 17 September 2010

\section{References}

1. Hussain I, Powell D, Howlett DR, Tew DG, Meek TD, Chapman C, Gloger IS, Murphy KE, Southan CD, Ryan DM, et al: Identification of a novel aspartic protease (Asp 2) as beta-secretase. Mol Cell Neurosci 1999, 14:419-427.

2. Sinha S, Anderson JP, Barbour R, Basi GS, Caccavello R, Davis D, Doan M, Dovey HF, Frigon N, Hong J, et al: Purification and cloning of amyloid precursor protein beta-secretase from human brain. Nature 1999, 402:537-540.

3. Vassar R, Bennett BD, Babu-Khan S, Kahn S, Mendiaz EA, Denis P, Teplow DB, Ross S, Amarante P, Loeloff R, et al: Beta-secretase cleavage of Alzheimer's amyloid precursor protein by the transmembrane aspartic protease BACE. Science 1999, 286:735-741.

4. Yan R, Bienkowski MJ, Shuck ME, Miao H, Tory MC, Pauley AM, Brashier JR, Stratman NC, Mathews WR, Buhl AE, et al: Membrane-anchored aspartyl protease with Alzheimer's disease beta-secretase activity. Nature 1999, 402:533-537.

5. Nowotny P, Kwon JM, Chakraverty S, Nowotny V, Morris JC, Goate AM: Association studies using novel polymorphisms in BACE1 and BACE2. Neuroreport 2001, 12:1799-1802.

6. Kirschling CM, Kolsch H, Frahnert C, Rao ML, Maier W, Heun R: Polymorphism in the BACE gene influences the risk for Alzheimer's disease. Neuroreport 2003, 14:1243-1246.

7. Zetterberg $\mathrm{H}$, Andreasson U, Hansson O, Wu G, Sankaranarayanan S, Andersson ME, Buchhave P, Londos E, Umek RM, Minthon L, et al: Elevated cerebrospinal fluid BACE1 activity in incipient Alzheimer disease. Arch Neurol 2008, 65:1102-1107.

8. Zhong Z, Ewers M, Teipel S, Burger K, Wallin A, Blennow K, He P, McAllister C, Hampel H, Shen Y: Levels of beta-secretase (BACE1) in cerebrospinal fluid as a predictor of risk in mild cognitive impairment. Arch Gen Psychiatry 2007, 64:718-726.

9. McKhann G, Drachman D, Folstein M, Katzman R, Price D, Stadlan EM: Clinical diagnosis of Alzheimer's disease: report of the NINCDS-ADRDA Work Group under the auspices of Department of Health and Human Services Task Force on Alzheimer's Disease. Neurology 1984, 34:939-944.

10. Wu G, Sankaranarayanan S, Tugusheva K, Kahana J, Seabrook G, Shi XP, King E, Devanarayan V, Cook JJ, Simon AJ: Decrease in age-adjusted cerebrospinal fluid beta-secretase activity in Alzheimer's subjects. Clin Biochem 2008, 41:986-996.

11. Blennow K, Wallin A, Agren H, Spenger C, Siegfried J, Vanmechelen E: Tau protein in cerebrospinal fluid: a biochemical marker for axonal degeneration in Alzheimer disease? Mol Chem Neuropathol 1995, 26:231-245.

12. Vanderstichele H, Van Kerschaver E, Hesse C, Davidsson P, Buyse MA, Andreasen $\mathrm{N}$, Minthon L, Wallin A, Blennow K, Vanmechelen E: Standardization of measurement of beta-amyloid(1-42) in cerebrospinal fluid and plasma. Amyloid 2000, 7:245-258.

13. Prince JA, Feuk L, Howell WM, Jobs M, Emahazion T, Blennow K, Brookes AJ: Robust and accurate single nucleotide polymorphism genotyping by dynamic allele-specific hybridization (DASH): design criteria and assay validation. Genome Res 2001, 11:152-162.
14. Blennow K, Ricksten A, Prince JA, Brookes AJ, Emahazion T, Wasslavik C, Bogdanovic N, Andreasen N, Batsman S, Marcusson J, et al: No association between the alpha2-macroglobulin (A2M) deletion and Alzheimer's disease, and no change in A2M mRNA, protein, or protein expression. $J$ Neural Transm 2000, 107:1065-1079.

15. Eyre TA, Ducluzeau F, Sneddon TP, Povey S, Bruford EA, Lush MJ: The HUGO Gene Nomenclature Database, 2006 updates. Nucleic Acids Res 2006, 34:D319-321.

16. Blacker D, Bertram L, Saunders AJ, Moscarillo TJ, Albert MS, Wiener $H$, Perry RT, Collins JS, Harrell LE, Go RC, et al: Results of a high-resolution genome screen of 437 Alzheimer's disease families. Hum Mol Genet 2003, 12:23-32.

17. Murphy T, Yip A, Brayne C, Easton D, Evans JG, Xuereb J, Cairns N, Esiri MM, Rubinsztein DC: The BACE gene: genomic structure and candidate gene study in late-onset Alzheimer's disease. Neuroreport 2001, 12:631-634.

18. Clarimon J, Bertranpetit J, Calafell F, Boada M, Tarraga L, Comas D: Association study between Alzheimer's disease and genes involved in Abeta biosynthesis, aggregation and degradation: suggestive results with BACE1. J Neurol 2003, 250:956-961.

doi:10.1186/1750-1326-5-37

Cite this article as: Sjölander et al:: BACE1 gene variants do not influence BACE1 activity, levels of APP or A $\beta$ isoforms in CSF in Alzheimer's disease. Molecular Neurodegeneration 2010 5:37.

\section{Submit your next manuscript to BioMed Central and take full advantage of:}

- Convenient online submission

- Thorough peer review

- No space constraints or color figure charges

- Immediate publication on acceptance

- Inclusion in PubMed, CAS, Scopus and Google Scholar

- Research which is freely available for redistribution

Submit your manuscript at www.biomedcentral.com/submit
Ciomed Central 